\title{
NIKAH ONLINE DALAM PERSPEKTIF
}

\author{
Miftah Farid \\ STMIK Bina Adinata Bulukumba \\ Universitas Islam Negeri (UIN) Alauddin Makassar \\ Email: Miftahfarid1989@gmail.com
}

\begin{abstract}
Growth of technology in this time send society [go] to media telecommunications globalization and of informatika. [At] condition in this time many problemss of arising out in a[n akad [pass/through] electronic media, for example marrying online which [is] its wedding ceremony transaction [pass/through] situation of activity or konektivitas which incircuit with a[n system or network of internet ( via online). Early from problem above, fiqh as product idea of human being related to Islam law have to can give answer of yuridis to change that happened in society. On that account, opportunity of study of fiqih have to be open ever, and must be done by paying attention social implications of applying of products idea of [his/its] law, beside remain to take care of its[his] [him/it] with doctrines will;desire of al-Qur'an about human being behaviour.
\end{abstract}

Keyword : Online Marry

\begin{abstract}
Abstrak
Perkembangan teknologi saat ini mengantarkan masyarakat menuju globalisasi telekomunikasi media dan informatika. Pada kondisi saat ini banyak permasalahan-permasalahan yang timbul dalam suatu akad melalui media elektronik, misalnya nikah online yang transaksi ijab kabulnya dilakukan melalui keadaan konektivitas atau kegiatan yang terhubung dengan suatu jaringan atau sistem internet (via online). Berawal dari persoalan di atas, fiqh sebagai produk pemikiran manusia yang berkaitan dengan hukum Islam harus mampu memberikan jawaban yuridis terhadap perubahan yang terjadi dalam masyarakat. Oleh sebab itu, peluang kajian fiqih harus senantiasa terbuka, dan harus dilakukan dengan memperhatikan implikasi-implikasi sosial dari penerapan produk-produk pemikiran hukumnya itu, disamping tetap menjaga relevansinya dengan kehendak doktrin-doktrin al-Qur'an tentang tingkah laku manusia.
\end{abstract}

\section{Kata Kunci : Nikah, Online}




\section{PENDAHULUAN}

Suatu akad pernikahan apabila telah memenuhi segala rukun dan syaratnya secara lengkap menurut yang telah ditentukan seperti menurut hukum Islam ataupun perundang-undangan, maka akad pernikahan yang demikian itu disebut akad pernikahan yang sah dan mempunyai implikasi hukum. ${ }^{1}$

Selain itu ada sebuah kesepakatan bahwa pernikahan itu dipandang sebagai sebuah akad. Akad (kontrak) yang terkandung dalam isi UU No 1/1974 dan KHI sebenarnya merupakan pengertian yang dikehendaki oleh undangundang. Acapkali disebut bahwa pernikahan adalah, "marriage in Islam is purely civil contract" (pernikahan merupakan suatu perjanjian semata). Yang berarti point of interest atau urgensi dari sebuah pernikahan adalah sebuah akad atau perjanjian. $^{2}$

Berdasarkan kerangka di atas, para ulama sepakat bahwa pernikahan dapat dinyatakan sah apabila dilaksanakan dengan sebuah akad, yang melingkupi ijab dan qabul antara seorang wanita yang dilamar dengan lelaki yang melamarnya, atau antara pihak yang menggantikannya seperti wakil atau wali, dan dipandang tidak sah jika semata-mata hanya berdasarkan suka sama suka tanpa adanya sebuah akad. ${ }^{3}$ Dengan demikian dapat dipahami bahwa ijab dan qabul merupakan tanah merupakan perjanjian tidak bernama yang muncul sebagai bentuk perkembangan perjanjian dalam masyarakat.

Unsur yang fundamental dan menjadi bagian esensi terhadap keabsahan suatu akad pernikahan. ${ }^{4}$ Karena dengan adanya ijab dan qabul, berarti ada yang mengucapkan ijab dan ada yang mengucapkan qabul, dan keberadaan keduanya

${ }^{1}$ Implikasi hukum yang muncul diantaranya adalah: 1). Kehalalan hubungan biologis antara suami isteri. 2). Tetapnya hak mahar bagi isteri menurut prosedur yang telah ditetapkan. 3). Timbulnya hak dan juga kewajiban yang berlaku bagi kedua belah pihak. 4). Tetapnya garis nasab anak yang terlahir dari pasangan suami isteri. 5). Garis batas kebebasan isteri. 6). Timbulnya larangan nikah bagi isteri yang terjerat tali pernikahan atau sebelum mempunyai iddah setelah bercerai atau ditinggal mati sang suami. Dan lain-lain. Abd. Shomad, Hukum Islam: Penormaan Prinsip Syariah Dalam Hukum Indonesia (Jakarta: Kencana, 2010), h. 280.

${ }^{2}$ Amir Nuruddin, Azhari Akmal Tarigan, Hukum Perdata Islam Di Indonesia (Studi KritisPerkembangan Hukum Islam dari Fikih, UU No. 1/1974 Sampai KHI) (Jakarta: Kencana Prenada Media Group, 2004), h. 47.

${ }^{3}$ Muhammad Jawad Mughniyah, Fiqih lima mazhab: Ja'fari, Hanafi, Maliki, Syafi'I, Hambali, penerjemah, Masykur A.B, Afif Muhammad, dkk (Jakarta: Lentera, 2010), h. 309.

${ }^{4}$ Para ulama bersepakat bahwa ijab dan qabul adalah rukun, karena dengan keduanya salah satu dari kedua mempelai mengikat diri dengan yang lain, sedangkan keridhaan adalah syarat. Lihat Wahbah Az-Zuhaili, Fiqih Islam Wa Adilatuhu, Terjm. Abdul Hayyie al-Kattani, dkk (Jakarta: Gema Insani, 2011), h. 45. 
yang saling terhubung dan berkaitan tersebut mengharuskan adanya objek dimana implikasi dari pengikatan itu muncul. ${ }^{5}$ Jika suatu akad pernikahan kurang satu atau beberapa rukun dan syaratnya maka pernikahan tersebut dipandang tidak sah. Tidak sahnya suatu akad pernikahan dapat terjadi diakibatkan tidak terpenuhinya salah satu diantara beberapa rukun, dan hal ini di kategorikan akad pernikahan yang batal (neiting), dapat pula terjadi diakibatkan tidak terpenuhinya salah satu syaratnya, dan hal ini di kategorikan akad pernikahan yang fasid (verniettigbaar).

Tulisan ini mencoba untuk memaparkan "Hukum Nikah Online dalam Tinjauan Hukum Islam dan Perundang-Undangan” dengan menyertakan data dan sumber yang penulis ketahui. Untuk mendapatkan gambaran dan pembahasan secara terpadu, tulisan ini disusun dengan urutan uraian pendahuluan, syarat keabsahan akad dalam pernikahan, nikah online dalam perspektif hukum, dan implikasinya terhadap penerapan pencatatan nikah.

\section{PEMBAHASAN}

\section{A. Syarat Keabsahan Akad dalam Pernikahan}

Ada beberapa persyaratan yang mesti terpenuhi untuk keabsahan suatu akad dalam pernikahan. Wahbah Az-Zuhaili dalam kitabnya Fiqh Islam WaAdillatuhu menjelaskan bahwa menurut kesepakatan para ulama, dalam shigat akad (ijab dan qabul) disyaratkan empat hal: ${ }^{6}$

1. Kesesuaian dan ketepatan kalimat ijab dengan qabul.

Kesesuaian itu dapat terwujud dengan adanya kesesuaian ijab dan qabul dalam tempat akad dan ukuran mahar. Jika ijab dan qabul berbeda, dan perbedaan itu terletak pada tempat akad, misalnya ayah perempuan berkata,"Aku menikahkanmu dengan khadijah," lantas si lelaki menjawab, "Aku menerima pernikahan Fatimah," maka pernikahan tidak sah. Itu dikarenakan isi dari kalimat qabul berbeda dengan apa yang disebutkan dalam kalimat ijab. Jika perbedaan itu terletak pada ukuran mahar, misalnya saja si wali perempuan berkata, "Aku nikahkan kamu dengan puteriku dengan mahar 1000 dirham," lantas si lelaki menjawab, "Saya terima nikahnya dengan mahar 800 dirham," maka pernikahannya tidak sah. Sebab tidak sahnya akad karena ada perbedaan dalam ukuran mahar, sekalipun mahar bukan merupakan rukun akad adalah bahwa

5 Abdul Karim Zaidan, Pengantar Studi Syari'at, judul asli Al-Madkhal li DirasatisySyari'atil-Islamiyyati, penj. M. Misbah (Jakarta: Robbani Press, 2008), h. 365.

${ }^{6}$ Wahbah Az-Zuhaili, Fiqih Islam Wa Adilatuhu, Terjm. Abdul Hayyie al-Kattani, dkk (Jakarta: Gema Insani, 2011). 
sesungguhnya jika mahar disebutkan di dalam akad maka ia menjadi bagian dari kalimat ijab.

2. Orang yang mengucapkan kalimat ijab tidak boleh menarik kembali ucapannya.

Di dalam akad disyaratkan bagi orang yang mengucapkan kalimat ijab untuk tidak menarik kembali ucapannya sebelum pihak yang lain mengucapkan kalimat qabul. Jika dia menarik kembali ucapannya maka ijabnya tersebut menjadi batal. Dengan demikian, tidak ada kalimat yang sesuai dengan kalimat qabul. Karena ijab dan qabul merupakan satu rukun. Dengan kata lain, salah satu dari keduanya haya meupakan setengah rukun saja.

3. Diselesaikan pada waktu akad.

Di dalam fikih empat mazhab tidak dibolehkan melakukan akad nikah untuk pernikahan diwaktu yang akan datang, misalnya dengan berkata "Aku akan menikahimu besok, atau lusa". Juga tidak membolehkan akad dengan dibarengi syarat yang tidak ada, seperti berkata, "Aku akan menikahimu jika Zaid datang", atau "jika ayah meridhai", atau berkata, "Aku akan menikahkanmu dengan putriku jika matahari telah terbit". Itu dikarenakan akad nikah termasuk akad pemberian hak kepemilikan atau penggantian. ${ }^{7}$ Disamping itu, telah dijelaskan di dalam KHI pada Pasal 27, yakni: "Ijab dan qabul antara wali dan calon mempelai pria harus jelas beruntun dan tidak berselang waktu". 8

\section{Dilakukan dalam satu majelis (ittihād al-majlis).}

Dilakukan dalam satu majelis (ittihād al-majlis) jika kedua belah pihak hadir. Jika pihak perempuan berkata, "Aku menikahkanmu dengan diriku", lantas pihak yang lain berdiri sebelum mengucapkan kata qabul, atau menyibukkan diri dengan perbuatan yang menunjukkan berpaling dari mejelis, kemudian setelah itu baru mengatakan, "Aku menerima", maka akad tersebut tidak sah. ${ }^{9}$ Hal ini

\footnotetext{
${ }^{7}$ Pernikahan itu disyaratkan harus langsung (berlakunya) sebab ia merupakan akad, sedangkan akad tidak terpisah oleh sebab-sebab yang ada padanya, sehingga tidak mungkin dikaitkan dengan masa yang akan datang. Lebih lanjut lihat Abu Zahrah dalam kitabnya Al-Ahwal Al-Syakhshiyyah (Qahirah: Dar al-Fikr al-'Arabi, 1957).

${ }^{8}$ Kompilasi Hukum Islam, Pasal 27.

${ }^{9}$ Imamiyah, Syafi'i dan Hambali berpendapat, diisyaratkan kesegeraan dalam akad. Artinya, qabul harus dilakukan segera setelah ijab, secara langsung dan tidak terpisah (oleh perkataan lain). Sementara itu Maliki berpendapat, pemisahan yang sekadarnya, misalnya oleh khutban nikah yang pendek dan sejenisnya tidak apa-apa.Sedangkan mazhab Hanafi tidak
} 
menunjukkan bahwa sekedar berdiri saja dapat mengubah majelis. Demikian juga jika pihak pertama meninggalkan majelis setelah mengucapkan kalimat ijab, lantas pihak kedua mengucapkan kata qabul di dalam majelis disaat pihak pertama tidak ada atau setelah kembalinya, maka itu juga dianggap tidak sah. ${ }^{10}$

\section{B. Hukum Nikah Online dalam Perspektif Hukum Islam}

Dalam menganalisa dan menyimpulkan pendapat ulama imam mazhab, sebelumnya harus dipahami dulu tentang nikah online dan kaitannya dengan interpretasi ittihād al-majelis, sehingga dengan memahami terlebih dahulu konteks keduanya, maka dapatlah kita menggali hukum dan menetapkan hukum dengan sebenar-benarnya. Agar dapatlah kita terhindar dari kemungkinan menetapkan hukum yang jauh dari kebenaran.

Nikah online adalah suatu bentuk pernikahan yang transaksi ijab kabulnya dilakukan melalui keadaan konektivitas atau kegiatan yang terhubung dengan suatu jaringan atau sistem internet (via online), jadi antara mempelai lelaki dengan mempelai perempuan, wali dan saksi itu tidak saling bertemu dan berkumpul dalam satu tempat, yang ada dan ditampilkan hanyalah bentuk visualisasi dari kedua belah pihak melalui bantuan alat elektronik seperti teleconference, webcame atau yang lainnya yang masih berkaitan dengan internet.

Nikah online dalam pengertian umum, ialah pernikahan yang komunikasinya dilakukan dengan bantuan komputer di kedua tempat, yang masing-masingnya dapat terhubung kepada file server atau network dan menggunakan media online sebagai alat bantunya. Media online sendiri ialah sebuah media yang berbasis telekomunikasi dan multimedia (komputer dan internet), didalamnya terdapat portal, website (situs web), radio-online, TV-online, pers online, mail-online, dan lain-lain, dengan karakteristik masing-masing sesuai dengan fasilitas yang memungkinkan user memanfaatkannya yang tentunya bersumber pada cacha server dan jaringan internet.

Nikah online sendiri jika dibandingkan dengan nikah biasa kalau dari penjelasan di atas, maka dapat disimpulkan bahwa tidak terdapat perbedaan secara substansional terhadap ritual pernikahan antara ritual pernikahan via online dengan ritual pernikahan seperti biasanya. Hal yang membedakan nikah online dengan nikah biasa adalah pada esensi ittihād al-majelis yang erat kaitannya

mensyaratkan kesegeraan.Lihat. Muhammad Jawad Mughniyah, Fiqih lima mazhab: Ja'fari, Hanafi, Maliki, Syafi'I, Hambali, penerjemah, Masykur A.B, Afif Muhammad, dkk, h. 311-312. h. 56-58.

${ }^{10}$ Wahbah Az-Zuhaili, Fiqih Islam Wa Adillatuhu, Terjm. Abdul Hayyie al-Kattani, dkk, 
dengan tempat (makan) pada implementasi atau pelaksanaan akadnya, namun selebihnya semuanya sama.

Kalau dalam pernikahan biasa antara pihak laki-laki dan perempuan dapat bertemu, bertatap muka dan berbicara secara langsung, begitupun dengan nikah online. Pada penerapan atau pelaksanaannya nikah online ini menggunakan kekuatan dari perkembangan teknologi untuk membantu dalam terlaksananya nikah agar dapat menyampaikan gambar kondisi individu yang sedang melakukan interaksi (teleconference) sebagaimana mestinya. Teknologi video teleconference lebih mutakhir dari telepon, karena selain menyampaikan suara, teknologi ini dapat menampilkan gambar atau citra secara realtime melalui jaringan internet. ${ }^{11}$

Nikah via online ini sendiri dapat difasilitasi dengan menggunakan proyektor (alat tembak) ke layar besar untuk menampilkan masing-masing pihak dan unsur-unsur yang ingin melangsungkan akad nikah. Hal ini untuk membuktikan dan membuat semua orang dapat melihat akad sebagaimana bertemu, berjumpa, bertatap muka secara langsung dan khususnya agar sebagaimana mestinya, serta disertakan juga alat pengeras suara sehingga semua orang dapat mendengar secara jelas sebagaimana yang dikehendaki pada nikah umumnya.

Adapun unsur pokok yang mendukung dan memperkuat pelaksanaan akad ini ialah ia menggunakan basis internet atau server sebagai alat kerjanya, yang dibantu dengan webcame, aplikasi-aplikasi TIK, seperti aplikasi otomatis perkantoran, surat elektronik, SMS, forum, knowledge, website, melalui fasilitas komunikasi telepon, internet maupun global internet dan sebagainya dalam hal penerapannya.

Dari penjelasan diatas, maka dapat diambil kesimpulan bahwa terdapat perbedaan mengenai esensi ittihād al-majelis atau adanya pergeseran kebudayaan dalam hal melakukan akad. Dimana dalam nikah biasa akad dilakukan dengan muwājahah bil ma'rüf (berhadap-hadapan secara langsung) pada satu tempat. Namun, untuk nikah online ini muwājahah bil ma'rüf sama-sama dilakukan, tapi tidak dengan tempatnya, dimana nikah online dilakukan dengan terpisahnya jarak antara yang melangsungkan akad. Untuk menentukan apakah seseorang itu dapat melaksanakan akad pernikahan melalui online, ditetapkan kriteria sebagai berikut:

${ }^{11}$ Ari Cahyo Nugroho, "Konstruksi Media Online Tentang Realitas Penyedotan Pulsa Analisi Framming Terhadap Berita Dalam Tribunnews.com, Jakarta: Masyarakat Telematika Dan Informasi." Jurnal Penelitian Teknologi Informasi dan Komunikasi, Vol. 3 No. 1 (2012): h. 29. 
1) Antara pria dan wanita yang ingin melangsungkan akad pernikahan haruslah terpisahkan jarak yang sangat jauh.

2) Tidak bisa berhadir karena alasan jarak dan memang dalam keadaan yang tidak memungkinkan bagi kedua belah pihak untuk bersatu dan berkumpul untuk melaksanakan akad sebagaimana mestinya.

Dengan menetapkan kriteria seperti diatas guna dapat dipastikan bahwa mereka yang melangsungkan akad nikah online adalah mereka yang memang tak dapat melangsungkan akad sebagaimana mestinya. Sehingga pernikahan online bagi mereka memang layak dilaksanakan sebagai alternatif atau jalan terang karena tak dapat melangsungkan akad nikah dengan alasan jarak dan waktu.

Berkaitan dengan pembuktian pelaksanaan nikah online terkait perangkat teknologi yang digunakan, dalam hal ini kita dapat memakai payung hukum pada Undang-Undang No. 11 Tahun 2008 Tentang Informasi dan Transaksi Elektronik Pasal 2, Pasal 3, pasal 4 butir (e), dan pasal 5 butir (1) dan (2), pasal 18 (2), pasal 27 (1), pasal 38 (1), pasal 40 (1) dan (2), serta pasal 45 (pidana), maupun pasalpasal yang lainnya, sesuai dengan keperluan kita terhadap permasalahan yang dialami. Dengan demikian, ketakutan sebagian orang dengan nikah online dimana oleh sebagian orang khususnya pihak perempuan nikah online itu rentan akan penipuan, dengan hal ini sudah dapat diatur atau dilindungi oleh Undang-Undang No. 11 Tahun 2008 Tentang Informasi dan Transaksi Elektronik. sehingga adanya unsur yang dapat merugikan bagi pihak-pihak terkait dapat langsung dilaporkan dan kemudian dipidanakan. Sesuai dengan bunyi pasal 27 (1) dan pasal 45 butir (1) yakni:

\section{Pasal 27}

(1) Setiap Orang dengan sengaja dan tanpa hak mendistribusikan dan/atau mentransmisikan dan/atau membuat dapat diaksesnya informasi Elektronik dan/atau Dokumen Elektronik yang memiliki muatan yang melanggar kesusilaan.

\section{Pasal 45}

(1) Setiap Orang yang memenuhi unsur sebagaimana dimaksud dalam pasal 27 ayat (1), ayat (2), ayat (3), atau ayat (4) dipidana penjara paling lama 6 (enam) tahun dan/atau denda paling banyak Rp. 1000.000.000.00 (satu miliar rupiah).

Dalam hal pembuktian ataupun penerapannya nikah online ini lebih dapat diterima dan diakui daripada nikah melalui media telepon, kalau nikah melalui media telepon oleh majelis hakim saja diperbolehkan, yang dalam hal ini cuma 
sekedar mendengar suara dari para pihak tanpa melihat kondisi fisik para pelaku, lalu bagaimana dengan nikah online yang dalam penerapannya jauh lebih maju dari pada nikah melakui media telepon, yakni di samping dapat didengar suaranya, juga dapat dilihat gambar yang sedang berbicara.

Dengan melihat apa yang tampak dari permasalah tersebut, dapatlah kita bandingkan kepada Putusan Pengadilan Agama Jakarta Selatan No. 1751/P/1989 tentang Pengesahan Praktik akad melaui media telepon. Jika majelis hakim sudah menetapkan nikah melalui media telepon saja di anggap sah, maka ketetapan itulah yang harusnya kita pegangi terkait nikah online. Dalam perundangundangan atau hukum positif yang ada di Indonesia, nikah online ini juga tak pernah disinggung sebelumnya, dan bahkan tidak ada peraturan yang mengaturnya, sehingga di Indonesia terkait hukum nikah online ini masih mengalami ke-absolut-an atau kekosongan hukum.

Dalam hal pernikahan di Indonesia kita dapat mengacu dan terikat pada peraturan yang tertulis pada UU No. 1/1974, ataupun juga KHI. Terkait pemaknaan pernikahan atau perkawinan sendiridalam UU No. 1/1974 pasal 1 hanya memberikan definisi perkawinan atau pernikahan sebagai suatu ikatan lahir batin antara seorang pria dengan seorang wanita sebagai suami isteri dengan tujuan membentuk keluarga (rumah tangga) yang bahagia dan kekal berdasarkan ketuhanan Yang Maha Esa. ${ }^{12}$ Selanjutnya dalam KHI pada Pasal 2 disebutkan bahwa perkawinan menurut hukum Islam adalah pernikahan, yaitu akad yang sangat kuat atau miśaqan ghaliźan untuk mentaati perintah Allah dan melaksankannya merupakan ibadah. ${ }^{13}$

Dapat dilihat bahwa dalam UU No. 1/1974 dan juga KHI hanya dijelaskan nikah secara umum, tak sedikitpun menyinggung masalah nikah online. Namun kalau dapat kita cermati dari bunyi pasal tersebut terdapat kata yang dapat kita tafsirkan terkait nikah online ini, bahwa dalam pasal tersebut menyebutkan salah satu tujuan pernikahan bahwa perkawinan atau pernikahan sebagai suatu ikatan lahir bathin antara seorang pria dan wanita sebagai suami isteri dengan tujuan membentuk keluarga (rumah tangga) yang bahagia, serta bertujuan untuk mentaati perintah Allah, yang artinya bahwa pernikahan pada dasarnya bertemunya seorang wanita dengan seorang lelaki yang bertujuan yang memang didasari untuk membentuk sebuah keluarga yang bahagia, entah konteks lewat pernikahan apapun, yang penting bahwa ia bertujuan untuk pernikahan yang bahagia dan kekal berdasarkan Kethanan Yang Maha Esa.

\footnotetext{
${ }^{12}$ UU No. 1 Tahun 1974, Pasal 1.

${ }^{13}$ Kompilasi Hukum Islam, Pasal 2.
} 
Selanjutnya jika dikaitkan dengan nikah online, berarti ia juga termasuk kategori nikah yang diakui oleh Negara selagi ia bertujuan untuk mentaati perintah Allah dan membentuk sebuah keluarga yang bahagia dan kekal berdasarkan Ketuhanan Yang Maha Esa. Dengan demikian jika kita berkaca pada penjelasan diatas dapat kita pahami bahwa dalam hal ini nikah online dapat diterima suatu keabsahannya baik dalam Islam maupun perundang-undangan yang berlaku.

\section{Analisis Penerapan Pencatatan Nikah Terhadap Implikasi Hukum Nikah Online}

Sebagai Negara hukum, Negara Indonesia selalu berpijak pada UU sebagai Konstitusi tertinggi, dan konstitusi tertinggi pada Negara Indonesia ialah UndangUndang Dasar Negara Republik Indonesia Tahun 1945.selanjutnya dalam hal munakahat (perkawinan) barulah kita bersandar pada UU No. 1/1974 Tentang Perkawinan. Berbicara nikah online, di dalam hukum Islam dan Undang-Undang Perkawinan sendiri tidak ada aturan yang secara eksplisit menjelaskan dan mengatur tentang hal ini. Entah dalam konteks keabsahan nikah onlinenya, atau bahkan dalam penerapan pencatatan nikahnya bagi mereka pelaku nikah online. Dengan demikian dapat dipastikan bahwa dalam hal ini terdapat kekosongan hukum yang berlaku di Indonesia saat ini, entah di dalam hukum Islam ataupun juga di dalam hukum positif di Indonesia.

Dalam penerapan pencatatan nikah bagi nikah online, pada dasarnya hal ini erat kaitannya dengan keabsahan suatu akad nikah online yang pada pembahasan sebelumnya sudah penulis uraikan tentang keabsahan nikah online, dan dengan uraian-uraian tersebut pembahasan penerapan pencatatan nikah bagi nikah online ini menjadi bersinergi dan menjadi pembahasan yang kompleks. Penerapan pencatatan nikah bagi mereka yang melangsungkan nikah online ini erat kaitannya dengan peristiwa penting lainnya dalam hal ini nikah biasa yang pada umumnya berlaku di Indonesia.yakni terkait legalitas dan pengakuan secara administratif dari Negara terhadap mereka yang melangsungkan pernikahan lewat media online. Dimana dalam UU No. 1/1974 dalam bunyi Pasal 2 Ayat 2 menyebutkan bahwa tiap-tiap perkawinan di catat menurut peraturan perundang-undangan yang berlaku, ${ }^{14}$ dan pada KHI Pasal 5 ayat (1) dijelaskan bahwa agar terjamin ketertiban perkawinan bagi masyarakat Islam setiap perkawinan harus dicatat. ${ }^{15}$

\footnotetext{
${ }^{14}$ 35UU No. 1 Tahun 1974, Pasal. 2 Ayat 2

${ }^{15}$ Kompilasi Hukum Islam, Pasal 5 Ayat 1.
} 
Dari bunyi pasal-pasal tersebut menegaskan Negara dalam hal ini Undangundang mengatakan bahwa tiap-tiap perkawinan dicatat menurut peraturan perundang-undangan yang berlaku, dan hal ini sudah menjadi jelas, bahwa kita sebagai masyarakat hukum terikat pada tata aturan yang dibuat oleh hukum. Negara kita adalah Negara hukum, dengan demikian dapat kita pahami bahwa, segala urusan di Negara Indonesia ini wajib berjalan berdasarkan norma-norma atau aturan-aturan hukum yang berlaku. Demikian juga bagi pencatatan nikah Dalam UU Perkawinan sebagaimana dijelaskan di atas, ia menjadi prasyarat bagi mereka yang ingin mendapatkan pengakuan di mata perundang-undangan atau hukum Indonesia.

Terkait dalam hal pencatatan nikah terhadap nikah online, hal ini tak bisa terlepas dengan peraturan perundang-undangan sendiri, dimana ia menuntut dan menjamin bahwa perkawinan adalah sah, apabila dikakukan menurut hukum masing-masing agamanya dan keperayaannya itu. ${ }^{16}$ Dengan demikian jika berdasar pada bunyi teks UU No. 1/1974 pasal 2 (1) tersebut dapat dipahami bahwa Negara menjamin dan mengakui perkawinan yang sah, apabila dilakukan menurut hukum masing-masing agamanya dan keperayaanya itu. Pernikahan online sendiri masih menjadi isu hangat yang terjadi sampai saat ini, hal ini terkait dengan keabsahannya di dalam hukum agama Islam.

Permasalahan ini sangat kompleks dimana masih adanya keabsolutan mengenai keabsahannya nikah online menurut hukum agama, yang dalam hal ini tentu kesimpulan mengenai diskursus nikah online dalam hal agama berimplikasi penuh pada penerapan pencatatan nikah di Indonesia, dimana ketika nikah online ini diterima dan dianggap sah oleh agama, maka mutlak hukum Negara menerima dan memfasilitasi penerapan pencatatan nikahnya, hal ini sebagai impact atau implikasi dari hukum nikah online sebagaimana terkait dalam bunyi KHI Pasal 4 perkawinan adalah sah, apabila dilakukakan menurut hukum Islam sesuai dengan UU No. 1/1974 Pasal 2 (1), bahwa perkawinan adalah sah, apabila dilakukan menurut hukum masing-masing agamanya dan keperayaannya itu. Penerapan pencatatan nikah ini juga suatu kemutlakan dari Negara kalau kita kaitkan dengan bunyi pasal 28 D pada UUD Tahun 1945 dimana setiap orang berhak atas pengakuan, jaminan, perlindungan, dan kepastian hukum yang adil serta perlakuan yang sama dihadapan hukum. ${ }^{17}$ Dengan bunyi pasal tersebut dapat kita pahami bahwa artinya umat Islam yang telah melaksanakan pernikahan menurut agamanya dan keperayaannya itu, mutlak dan berhak mendapatkan sebuah

${ }^{16}$ UU No. 1 Tahun 1974 Pasal 2 Ayat 1

${ }^{17}$ UUD 1945, Pasal 28 D 
kepastian hukum dan perlakuan yang sama dihadapan hukum. Begitu juga dengan hukum bagi nikah online dan penerapannya dalam hal ini pencatatan nikah terhadap nikah online.

Terkait definisi pernikahan atau perkawinan yang termaktub dalam UU No. 1/1974 Pasal 1 yang berbunyi perkawinan ialah ikatan lahir batin antara seorang pria dengan seorang wanita sebagai suami isteri dengan tujuan membentuk keluarga (rumah tangga) yang bahagia dan kekal berdasarkan ketuhanan Yang Maha Esa. Kemudian juga definisi pernikahan yang termaktub dalah KHI Pasal 2 yang berbunyi perkawinan menurut hukum Islam adalah pernikahan, yaitu akad yang sangat kuat mitsaqan ghalidzan untuk mentaati perintah Allah dan melaksanakannya merupakan ibadah. Dan selanjutnya pada bunyi KHI pasal 3 dimana perkawinan bertujuan untuk mewujudkan kehidupan rumah tangga yang sakinah, mawaddah, dan rahmah.

Maka kalau kita cermati kata perkawinan pada bunyi pasal tersebut bersifat universal bagi siapa saja yang ingin melangsungkan pernikahan, dalam hal ini dapat ditafsirkan pernikahan dalam bentuk apapun. Meskipun bunyi pasal tersebut bersifat universal namun, bunyi pasal tersebut juga deferensial, karena esensi dari perkawinan sendiri yang dapat ditafsirkan pada ayat tersebut ialah apabila bertujuan membentuk keluarga (rumah tangga) yang bahagia dan kekal berdasarkan ketuhanan Yang Maha Esa, atau karena mentaati perintah allah, atau karena bertujuan mewujudkan kehidupan rumah tangga yang sakinah, mawaddah, dan rahmah. Dengan demikian, dapat kita pahami bahwa, bukan saja pernikahan biasa atau pernikahan pada umumnya yang dianggap sebuah perkawinan dalam kacamata perundang-undangan, melainkan juga nikah online. Selama dalam pelaksanaannya bertujuan membentuk keluarga (rumah tangga) yang bahagia dan kekal berdasarkan ketuhanan Yang Maha Esa, atau karena mentaati perintah Allah SWT, atau karena bertujuan mewujudkan kehidupan rumah tangga yang sakinah, mawaddah, dan rahmah. Maka selama itupula ia tidak ada bedanya dengan nikah pada umumnya.

Dalam konteks ini pula ia menjadi suatu implikasi kemutlakan dan keharusan dalam hal penerapan hukum pencatatan nikah, karena tentunya sebagai Negara hukum, maka adalah suatu kewajiban melaksanakan pernikahan atau perkawinan berdasarkan peraturan yang berlaku. Dimana sudah ditegaskan dalam UU No. 1/1974 pasal 2 ayat 2 yang berbunyi: "Tiap-tiap perkawinan dicatat menurut peraturan perundang-undangan yang berlaku." ${ }^{18}$ Demikian berdasarkan penjelasan di atas dapat kita simpulkan bahwa dasar dari administrasi nikah dalam

${ }^{18}$ UU No. 1 Tahun 1974 Pasal 2 Ayat 2 
hal ini penerapan pencatatan nikah sebagai implikasi nikah online bagi masyarakat yang beragam Islam adalah berdasarkan pada penjelasan dari UU No. 1/1974 Pasal 2 (2), dan KHI Pasal 5 (1).

Selanjutnya, apabila permohonan nikah online ditolak atau tidak dapat dikabulkan oleh pihak Pengadilan Agama, mereka yang berkehendak melangsungkan akad nikah tersebut dapat melakukan upaya lainnya yakni banding ke Pengadilan Tinggi Agama. Selanjutnya apabila mereka tetap ditolak oleh Pengadilan Tinggi Agama, maka upaya terakhir yang dapat mereka tempuh ialah upaya hukum kasasi ke Mahkamah Agung.

\section{PENUTUP}

Sebagai masyarakat yang memegang teguh nilai keagamaan, alangkah baiknya mampu melaksanakan praktek suatu perbuatan hukum agar mengetahui apa yang dilaksanakan tersebut dan mencari dasar hukumnya. Karena permasalahan baru yang muncul dalam masyarakat semakin berkembang terutama yang berhubungan dengan perkembangan teknologi. Untuk itu perlu kiranya diadakan kajian yang mendalam pada hukum Islam, agar sesuai dengan ketetapan hukum positif yang berlaku, serta dapat dipahami lebih jelas dan sesuai dengan konteks masyarakat sekarang ini. 


\section{DAFTAR PUSTAKA}

Abdurrahman, Kompilasi Hukum Islam di Indonesia, Jakarta: Akademika Presindo, 1992

Faruk, Nanang Husni, Analisis Hukum Islam Terhadap Pasal 29 Ayat 2 Kompilasi Hukum Islam (KHI) Tentang Qabul Nikah Yang diwakilkan, Skripsi Fakultas syari'ah, IAIN Walisongo Semarang, 2008

Harahap, M. Yahya, Pengadilan Agama dan Kompilasi Hukum Islam Dalam Tata Hukum Indonesia, Yogyakarta: UII Press, 1993

Kuzairi, Achmad, Nikah Sabagai Perikatan, Raja Grafindo Persada, Cet. 1, Jakarta. 1995

Mughniyah, Muhammad Jamal, Fiqih lima mazhab: Ja'fari, Hanafi, Maliki, Syafi'I, Hambali, penerjemah, Masykur A.B, Afif Muhammad, dkk. Jakarta: Lentera, 2010

Nuruddin, Amir, Azhari Akmal Tarigan, Hukum Perdata Islam Di Indonesia (Studi KritisPerkembangan Hukum Islam dari Fikih, UU No. 1/1974 Sampai KHI). Jakarta: Kencana Prenada Media Group, 2004.

Rosyada, Dede, Hukum Islam dan Pranata Sosial, Jakarta; Rajawali Pers, 1993.

Shomad, Abd, Hukum Islam: Penormaan Prinsip Syariah Dalam Hukum Indonesia. Jakarta: Kencana, 2010

Tim Redaksi Fokus Media, Kompilasi Hukum Islam. Bandung: Fokus Media, 2007.

Winarno, Ifan Tri, Pertimbangan Hakim Dalam Penggunaan Media Sosial Sebagai Alat Bukti Dalam Perkara Pidana Di Pengadilan Negeri Yogyakarta, Skripsi Fakultas syari'ah dan hukum, UIN Sunan Kalijaga Yogyakarta, 2014.

Zahrah, Abu, Al-Ahwal Al-Syakhshiyyah. Qahirah: Dar al-Fikr al-'Arabi, 1957.

Zaidan, Abdul Karim, Al-Madkhal li Dirasatisy-Syari'atil-Islamiyyati, Jakarta: Robbani Press, 2008.

\section{Peraturan Perundang-Undangan}

Undang-Undang Nomor 1 Tahun 1974 Tentang Perkawinan

Undang-Undang Nomor 11 Tahun 2008 Tentang Informasi Dan Transaksi Elektronik

Peraturan Pemerintah Nomor 9 Tahun 1975 Tentang Pelaksanaan Undang Undang Nomor 1 Tahun 1974

Instruksi Presiden Nomor 1 Tahun 1991 Tentang Kompilasi Hukum Islam 